\title{
TECHNOLOGY INTEGRATION IN AN INDONESIAN EFL WRITING CLASSROOM
}

\author{
Yustinus Calvin Gai Mali ${ }^{a}$, Thomas Lee Salsbury ${ }^{\mathrm{b}}$ \\ ('yustinus.mali@uksw.edu, btsalsbury@wsu.edu) \\ Universitas Kristen Satya Wacana \\ Jl. Diponegoro 52-60 Salatiga, Indonesia, 50711
}

\author{
Washington State University, Pullman Campus \\ Cleveland Hall 330, Pullman, Washington State, USA 99164
}

\begin{abstract}
The global, national, and local top-down technology-related policies and initiatives indicate the essential place of technology in education. However, little is known about classroom-based and self-reflective understandings of how the integration of technology can facilitate or distract students' writing processes in the context of higher education in Indonesia, specifically from the eyes of English as a Foreign Language (EFL) writing lecturers in the country. In response, this qualitative study aims to delve closely into the lecturers' reflection of integrating technology to support their students in completing English language learning tasks in an EFL writing classroom. Data were gathered from three female writing lecturers. They completed four self-reflective checklists and were interviewed to clarify the checklists and their technological practices related to five stages of process writing, namely planning, drafting, editing, revising, and submitting. The analysis of the data indicated that the most successful experiences in using technology were in the planning stage. Meanwhile, technology applications in the drafting, editing, and revising phases were mainly used to submit work and provide feedback. Various technology applications used in the writing class, some issues in using the technology in the writing stages, and directions for further research are discussed.
\end{abstract}

Keywords: EFL writing, language teaching, reflection, technology integration

DOI: http://dx.doi.org/10.15639/teflinjournal.v32i2/243-266

Top-down initiatives to maximize the use of technology in foreign language instructions have been established in several countries around the world, such as in South Korea (Sanchez et al., 2011), China (Li \& Ni, 2011), Bangladesh (Parvin \& Salam, 2015), and Rwanda (Sylvestre et al., 2018). 
Southeast Asian countries, such as Malaysia and Vietnam, are also reported to support technology integration in their national education. In Malaysia, the government made a significant investment in facilitating Information and Communication Technology (ICT) integration, such as by providing hardware, software, infrastructure, professional development, and Internet access in schools to enhance the teaching and learning quality of the country (Singh \& Chan, 2014; Umar \& Yusoff, 2014). In Vietnam, the Ministry of Education and Training has encouraged the adoption of ICT-based learning in teacher-training programs and higher education throughout the country (UNESCO Asia Pacific Regional Bureau for Education, 2013).

In Indonesia, a national policy called Indonesian Qualification Framework (henceforth IQF) was established to equalize every Indonesian citizen's work training and experience to compete in a workplace either inside or outside the country. From the nine levels of work descriptions specified in the IQF (for more details, see Directorate General of Higher Education Ministry of Education and Culture Republic of Indonesia, 2015), level six reflects the competencies that graduates with a Bachelor's Degree need to possess. The competencies emphasize the necessity of technology integration (see Mali \& Timotius, 2018). The work competencies in level six have gradually been translated into learning activities in Indonesian universities through their vision and mission statements. The global (e.g., in some of the countries), national (e.g., IQF), and local (e.g., at Indonesian universities) top-down related policies and initiatives have indicated an essential place of technology in education.

In more specific educational settings, such as in English as a Foreign Language (EFL) writing classes, various uses of technology have been well documented by previous studies, such as the use of Facebook's online discussion (Yu, 2018), Wikis for collaborative writing (Aydin \& Yildiz, 2014), Google Classroom (Torabi, 2021) and Edmodo (Safdari, 2021) to contribute to students' writing accuracy, and Blog to decrease students' writing difficulties (Chang, 2020). Although all the technology uses were reported to help the students enhance their writing in various ways, teachers' in-depth reflection on how they utilize technology in their EFL writing classrooms (beyond statistical numbers of students' perceptions as reported by the previous studies) should be discussed more sufficiently.

Dewey (1933) wrote, "We do not learn from experience; we learn from reflecting on experience" (p. 78). In this same spirit, we argue that reflection is a point of departure for teachers to look more closely at technology practices in their EFL writing classes, find areas of improvement, and take real and more active steps to solve challenges in using technology in the 
writing classrooms. Reflection here refers to "an approach where teachers actively collect data about their teaching beliefs and practices and then reflect on the data to direct future teaching decisions" (Farrell, 2015a, p. 8). Through systematic reflection practice, teachers can discern teaching and learning related benefits of technology from compliance with the national policy.

The reflective practice implemented in this study meets the following criteria. First, it is broad in scope, going beyond exploring the benefits or problems of using technology in a class, such as Edmodo (Al-Kathiri, 2015), Blog (Mali, 2015), or smartphone apps (Mindog, 2016). Second, reflective practices in previous research have been analyzed through the use of questionnaires to explore types of technology used in classrooms and teachers' attitudes towards that technology (e.g., Cahyani \& Cahyono, 2012; Celik, 2013; Cummings, 2008; Park \& Son, 2009; Ruggiero \& Mong, 2015; Son et al., 2011). While these studies have revealed important trends in the use of and attitudes towards technology, in this article, we responded to the call from several researchers (e.g., Aydin, 2013; Pang, 2017; Singh \& Chan, 2014) for more investigations of teachers' reflections on their teaching practices and the actual use of technology for supporting their teaching and learning.

Further, the majority of the previous studies were related to descriptive accounts of experiences written chronologically (e.g., Pearcy, 2014) supported with actual examples and approached using a single method, such as either action research (e.g., Pardo \& Tellez, 2015) or autoethnography (e.g., Lewis, 2018). However, empirical findings that posit a reflective and replicable framework consisting of self-reflective checklists or questions to guide EFL teachers to reflect on their teaching practices with technology in their EFL writing classroom do not seem to be widely published in the previous studies. Very few empirical endeavors have also reflected technology integration in an EFL writing class in Indonesia's higher education contexts.

The purpose of the current study is to understand how Indonesian lecturers integrate technology in the writing process and their perceptions of both benefits and hindrances of technology to their students when completing writing tasks. In this study, we developed an online reflection checklist and a list of interview questions. The specific, interconnected research questions to answer in this study are: (1) How do the lecturers use technology to support their students in every stage of their EFL writing process? (2) How do the lecturers reflect on ways technology integration hinders or facilitates the students to complete their EFL writing tasks? 
The study was approached qualitatively to view real-world situations (Fraenkel \& Wallen, 2009) in rich detail to examine complex questions that cannot be answered quantitatively (Ary et al., 2019). Following Clandinin (2006), we collaborated with our research participants through a series of social interactions over time to answer the research questions.

\section{METHOD}

The study setting was in an EFL writing class at the English Language Education Program of Pengharapan University (pseudonym) in Indonesia (hereafter called ED-PU). ED-PU prepares its students to become English language teachers in the future. The study program also has an explicit mission statement that encourages lecturers to integrate technology and maximize its potential into their teaching and learning practices. In line with the mission statement, the students, as future English language teachers and holders of the Bachelor's Degree in English Education, are required to perform specific working descriptions stated in level 6 of IQF. For instance, they have to be able to utilize ICT in their expertise, adapt to various situations, and solve a particular problem (see Directorate General of Higher Education Ministry of Education and Culture Republic of Indonesia, 2015). The selected class was held in the second semester, in which technology was usually implemented to facilitate students' learning activities. We hoped that by studying the second-semester writing class, we might provide an earlier understanding of how lecturers could enhance their teaching instructions with better and wiser use of technology. The students in the class worked in pairs to write a procedural essay (how to do something), and most of the writing activities were done inside the classroom.

The lecturers' reflection in the course was focused on the writing activities of paragraph writing, which, as stated in the class syllabus, asked the students to engage in process-oriented approaches to writing. The approaches have five main phases. The first phase is planning. The students brainstormed, took notes, and developed initial ideas; they gathered information from people or texts. The students also wrote an outline of their essay and discussed it with their friends. "Grammatical mistakes are not taken into account, as this initial stage of the writing process is mainly intended to build up students' confidence to write" (Laksmi, 2006, p. 150). The second phase is drafting. The students started to develop a structured written text from the notes and the outline they had in the planning stage. The third phase is revising. At this phase, the students identified their writing problems related to grammar, spelling, punctuation, style, clarity, and other 
related problems and received feedback from their lecturers. The students might add words, change phrases, rewrite sentences, and improve their writing in the first draft. The next phase is editing or "putting the piece of writing into its final form" (Tompkins, 1994, p. 21). After finishing the revision phase, the students went back over their writing and made necessary changes, such as in "organization, style, grammatical and lexical correctness, or appropriateness" (Nation, 2009, p. 120). The students edited their work based on their lecturer's feedback. Then, they wrote a clean copy of the revised version before submitting their final work. Harmer (2007) noted that the process approaches were often made recursively; therefore, the students could go back to the planning stage and think again about their writing ideas even after preparing the final version of their work. Lastly, in the submitting stage, the students wrote a final written work, and they submitted it to their lecturer without publishing the work for an audience outside classrooms (e.g., through a blog, online magazine, or academic journal).

Three EFL writing lecturers participated as research subjects. They were selected because they taught first-year students. They also welcomed us to provide constructive inputs for their technological practices in the writing class and agreed to commit to the reflection practices in four weeks. For anonymity reasons, we used pseudonyms for the participants: Linda (teacher 1), Sandra (teacher 2), and Calesia (teacher 3). All participants are Indonesian female EFL lecturers who teach in the same university, as outlined in Table 1. Because the first author of this paper (hereafter called C) is also an Indonesian, this gave us a window into their communication styles and norms. We could hope that the participants would tell rich reflective stories on various teaching and learning events without experiencing many communication breakdowns. Our role in this study was more as a friend than as a researcher to encourage the participants to reflect on their practices in an open and trusting situation.

Table 1. The Research Participants

\begin{tabular}{|l|l|l|l|}
\hline Information & Linda & Sandra & Calesia \\
\hline Gender & Female & Female & Female \\
\hline Age & 44 years old & 45 years old & 38 years old \\
\hline $\begin{array}{l}\text { Degree } \\
\text { (highest) }\end{array}$ & $\begin{array}{l}\text { Master's Degree } \\
\text { in Education from } \\
\text { an Indonesian } \\
\text { university }\end{array}$ & $\begin{array}{l}\text { Master's Degree } \\
\text { in Education from } \\
\text { an Indonesian } \\
\text { university }\end{array}$ & $\begin{array}{l}\text { Master's Degree } \\
\text { in Education from } \\
\text { an Indonesian } \\
\text { university }\end{array}$ \\
\hline
\end{tabular}




\begin{tabular}{|l|l|l|l|}
\hline Information & Linda & Sandra & Calesia \\
\hline $\begin{array}{l}\text { Total years of } \\
\text { teaching } \\
\text { experience }\end{array}$ & 21 years & 6 years & 13 years \\
\hline Nationality & Indonesian & Indonesian & Indonesian \\
\hline
\end{tabular}

Initially, $\mathrm{C}$ emailed the participants about the research purposes and responded to any questions they might raise. Each participant read and signed an informed consent statement. After obtaining the consent, $\mathrm{C}$ forwarded a set of reflective checklists (see Table 2) and an interview protocol to the participants so that they had some time to reflect on their experiences and prepare their answers before the interview.

Table 2. The Self-Reflective Checklist

\begin{tabular}{|c|l|c|c|}
\hline No & Close-Ended Statements & Yes & No \\
\hline 1 & $\begin{array}{l}\text { I instruct my students to use technology to support their } \\
\text { writing process }\end{array}$ & & \\
\hline 2 & I explain the purpose of why the technology is used. & $\begin{array}{l}\text { The technology used in today's class supports my students' } \\
\text { writing process }\end{array}$ & \\
\hline No & Open-Ended Statements & $\begin{array}{l}\text { (If the technology is used in the writing class) Please mention the name of } \\
\text { the technology! }\end{array}$ \\
\hline 5 & $\begin{array}{l}\text { What do you learn from the experiences of using technology in teaching } \\
\text { writing in the class? }\end{array}$ \\
\hline
\end{tabular}

There were two stages of data collection. In the first stage, the participants filled in the checklist after the class session to capture learning activities they did with technology and "the kinds of activities that worked well or did not work well" (Farrell, 2015a, p. 84). In total, there were four reflective checklists to complete. The checklist was designed and completed in the survey software called Qualtrics. Every week, C used the WhatsApp application to check in with the lecturers, remind them to complete the checklist, and clarify any questions they had. In the second stage, the participants were interviewed using Zoom, which could record the interview and save the recording on a laptop. The interview questions were developed from responses in the self-reflective checklist. $\mathrm{C}$ interviewed the participants, and the interview lasted for around 30 to 40 minutes. The interview questions (see Appendix) were sent through WhatsApp, and the participants could read 
the questions and ask for clarification in the weekly check-ins. The participants were allowed to use their first language, Indonesian, in the interview. The interview videos were transcribed and analyzed, and all the responses were translated into English. We then triangulated the data "to ensure the findings were credible: a piece of evidence was compared and cross-checked" (Farrell, 2015b, p. 29). The participants received a monetary incentive for their time commitment in completing the checklist and the interview session as described above.

The items in the checklist and interview questions should possess high reliability as we developed them systematically from the theoretical constructs of Farrell's (2015a) reflection framework coupled with the recent theories (e.g., Ferris \& Hedgcock, 2014; Kizil, 2017; Trinder, 2017) that address similar points as those stated in the framework. This strategy refers to theory triangulation, where multiple theories can support a phenomenon under study, and this is a powerful technique to promote the reliability of the qualitative inquiry (Ary et al., 2019). Muñoz and Ramirez (2015) used the same triangulation strategy to assure the validity of interview questions in their study.

Adapting Creswell's (2014) qualitative data analysis strategies, we prepared data for analysis (i.e., transcribing the video interview). We then attached the interview transcription in an email and allowed the participants to read and add some additional information if necessary. After they confirmed that the interview transcriptions were what they aimed to say, we read the interview data transcription repeatedly and then noted recurring phrases and sentences related to keywords in the research questions. We continued to taking some participants' responses and labeling them with a term. Then, we developed a final set of codes to describe what the participants did with the technology. Last, we summarized the data (see Table 3 ) and developed themes for interpretations. We emailed our data analysis to the participants. We allowed them to respond so that they had a chance to discuss our analysis and be in a better position to "identify problems and recommend effective solutions" (Gun, 2011, p. 133).

To ensure the research credibility, we employed the research trustworthiness strategies by Ary et al. (2019). First, we used corroborating evidence collected from heterogeneous data sources, such as the reflective checklist and the interview data. Previous researchers (e.g., Jiang, 2015; Lewis, 2018) also used multiple data sources to ensure their studies' trustworthiness. Second, we did a peer debriefing activity. C initially analyzed the data and presented the interpretations. The second author then read the interpretations and made some revisions when the interpretations 
were not reasonable. Next, we displayed verbatim quotations of data to present the participants' voices. We also explained our assumptions, beliefs, and social experiences that might shape our research data interpretations. For instance, at the time of the study, $\mathrm{C}$ was a doctoral student interested in integrating technology in classrooms. He also knew all the research participants well before the study, which might increase the likelihood of a biased interpretation.

Besides the biased interpretation, we also acknowledged other potential limitations in the current study. First, only three writing lecturers participated in this research; therefore, we did not want to generalize our findings to a broader context. Second, the monetary incentives we gave to the research participants might affect how they responded to the reflective checklist and interview questions. Third, we provided the participants with spaces to voice their personal experiences, and we involved our subjective interpretations of analyzing their narratives. We still believed that our participants were best studied through this subjective, dynamic lens, assuming that knowledge is not absolute (see Agada, 1998), stable, nor uniform across time (see Gage, 1989). Last, the study results were only based on the self-reflective checklist and the interview without actual class observations. Therefore, some technology-related issues in the writing class might remain untold.

\section{FINDINGS AND DISCUSSION}

\section{Findings}

This study aimed to explore: (a) how lecturers use technology to support their students in every stage of their EFL writing process; and (b) how the lecturers reflect on ways technology integration hinders or facilitates the students to complete their EFL writing tasks. In brief, previous researchers working in Indonesia (e.g., Cahyani \& Cahyono, 2012; Mali \& Timotius, 2018) have contextualized technology as electronic tools, software, and hardware intertwined with the Internet used for teaching and learning purposes. In this study, we limited the term technology to software and the Internet to facilitate the students' writing process. The subsequent sections will detail the lecturers' use of technology and their reflections on the technology integrations, which are expected to answer the scarcity of teachers' reflections on their teaching practices (as discussed by Almas \& Krumsvik 2008; Aydin, 2013; Pang 2017) and provide the actual use of technology for classroom learning to respond to the gap revealed by Singh and Chan (2014). 


\section{The lecturers' use of technology to support their students in their writing process}

Each lecturer used slightly different types of technology. Table 3 summarizes the technology that the lecturers used in the writing process. We decided to put the revising and editing stages into one category as the students, in both stages, received feedback and revised their writing based on the inputs they had from their friends or lecturer.

Table 3. The Overall Use of Technology in the Writing Process

\begin{tabular}{|c|c|c|}
\hline Stages & Writing Activities & Technology \\
\hline Planning & $\begin{array}{l}\text { The students collected } \\
\text { information, brainstormed, } \\
\text { took notes, developed } \\
\text { initial (outline of) ideas, } \\
\text { and discussed their outline } \\
\text { with one another. }\end{array}$ & $\begin{array}{l}\text { a. PowerPoint to display a } \\
\text { flowchart of the students' } \\
\text { essay } \\
\text { b. Creately.com to provide the } \\
\text { students with templates for } \\
\text { their flowchart } \\
\text { c. Online search to allow the } \\
\text { students to browse the Internet } \\
\text { and collect information for the } \\
\text { flowchart }\end{array}$ \\
\hline Drafting & $\begin{array}{l}\text { The students wrote a } \\
\text { structured written text } \\
\text { based on the notes } \\
\text { (outline) developed in the } \\
\text { previous stage. }\end{array}$ & $\begin{array}{l}\text { a. Google Docs to write the first } \\
\text { draft } \\
\text { b. Google Translate to help in } \\
\text { translating Indonesian words } \\
\text { into English } \\
\text { c. Cambridge or Merriam } \\
\text { Webster online dictionary to } \\
\text { find an appropriate vocabulary } \\
\text { to write in the essay } \\
\text { d. Email to receive the students' } \\
\text { work }\end{array}$ \\
\hline $\begin{array}{l}\text { Revising } \\
\text { and } \\
\text { Editing }\end{array}$ & $\begin{array}{l}\text { Problems in the students' } \\
\text { written work were } \\
\text { identified. The essay was } \\
\text { revised and rewritten based } \\
\text { on the lecturer's feedback. } \\
\text { A clean copy of the essay } \\
\text { was written. }\end{array}$ & $\begin{array}{l}\text { a. YouTube (Smart English } \\
\text { Channel) video to help } \\
\text { comprehend concepts of run- } \\
\text { on sentences and fragment in } \\
\text { a sentence } \\
\text { b. Email to send some written } \\
\text { feedback } \\
\text { c. Google Docs to provide } \\
\text { (online) input for the first } \\
\text { draft }\end{array}$ \\
\hline
\end{tabular}




\begin{tabular}{|c|l|l|}
\hline Stages & \multicolumn{1}{|c|}{ Writing Activities } & \multicolumn{1}{c|}{ Technology } \\
\hline & $\begin{array}{l}\text { d. The online dictionaries to find } \\
\text { appropriate vocabulary in the } \\
\text { essay } \\
\text { e. MS Word to write the students' } \\
\text { final draft }\end{array}$ \\
\hline Submitting & $\begin{array}{l}\text { The students only submitted the work to the lecturer, and they } \\
\text { did not publish their essays on the classroom walls, websites, } \\
\text { or academic journals. }\end{array}$ \\
\hline
\end{tabular}

Theme 1: PowerPoint was used to present a flowchart

The three lecturers seemed comfortable asking their students to create a flowchart before the draft was written. The flowchart was then put in a PowerPoint slide, and the students presented their flowchart in the classroom, as Linda described in the interview.

Before they started to write, I asked my students to create a flowchart, and they have to present their flowchart. My students did not find any difficulties in creating the flowchart. They even could add some pictures to their slides. (Linda, interview)

Calesia mentioned similar information that her students had to present their flowchart with pictures and arrows using PowerPoint. Sandra asked her students to visit a site (https://creately.com/) that provides many free templates to design their flowchart.

\section{Theme 2: Online search helped to collect ideas}

Sandra allowed her students to browse online websites to find related information in creating their outline, as evident in the interview:

I asked them to research for ideas they want to write for their essay. They could visit online websites as the writing topic was free. However, I reminded them to take ideas that they knew very well. Some students were interested in writing about how to borrow a book from a library, so I told them to visit the campus library's website to know more about the rules. (Sandra, interview)

Calesia allowed her students to use Google to help them collect ideas for their outline. However, she reminded her students not to copy-paste the available information or flowchart directly from the Internet. Linda allowed her students to use their mobile phones in the class to access online resources on the Internet. 
Theme 3: Video was used to respond to the students' common grammatical problems

After reading the first draft of the students' essays, Calesia found out that the run-on sentences and fragments were the most common grammatical problems in their writing. The students wrote a run-on sentence when they improperly connected two or more independent clauses. Meanwhile, a fragment occurred when the students wrote a sentence with a missing subject or a verb, which did not express a complete idea. Calesia decided to play a YouTube video she got from Smart English Channel (https://www.youtube.com/user/smrtenglish). Calesia believed that the video would attract her students' attention in listening to the explanations of runon sentences and fragments:

My purpose in using the video was to make students be used to listening to an explanation in English. The students were usually less enthusiastic in listening to their classroom teacher's talks. Therefore, I decided to use the video. I want to find an exciting way to explain grammar-related concepts. The video shows how to fix a fragment. For instance, the students have to see what is missing in a sentence. If the subject is missing, they have to add a subject; if the verb is missing, they have to add a verb. (Calesia, interview)

While watching the video, the students were asked to note down some essential points. Then, Calesia asked them some follow-up questions, such as what is a fragment? How can you fix the problems in your first draft? After answering these questions, the students reviewed their work and fixed similar problems in their writing.

\section{The lecturers' reflection on ways technology integration hinders or facilitates the students' writing process}

Theme 4: The use of flowchart and PowerPoint slide supported the planning stage

All three lecturers agreed that using a flowchart displayed in the PowerPoint slide helped the students in the planning stage. Calesia could ensure that her students had clear directions of ideas in their essay before they started to write.

When my students presented their flowchart, they had ideas in mind about what steps to do first and to do later. When I read their work, I could understand the flow of ideas in their writing. However, when they could not present clear ideas in the presentation, they would usually have scattered thoughts in their writing. (Calesia, interview) 
The flowchart presentation also enabled Sandra to see her students' ways of thinking. Some students have systematic ideas, while the others presented a confusing flow of ideas. Sandra gave feedback soon afterward. If necessary, she asked them to add more ideas. The flowchart presentation was followed by a question-and-answer section where classmates and the teacher could provide feedback focusing more on ideas presented in the flowchart.

\section{Theme 5: Giving feedback directly on the paper was preferable}

Two lecturers did not like to give online feedback. One day, Linda had to cancel her class as she had to attend a meeting in another town. She asked her students to send their first draft (in an MS Word file) through an email, and she gave her feedback directly in the email. When asked about her decision, she acknowledged some issues.

I did not finish giving the feedback to all my 22 students in one day. I did it day by day as my eyes could not stay long in front of the laptop. I found it challenging to give comments on technical aspects and grammar. Where should I put my comments? Mostly, I said that "there were many grammatical mistakes, please check." (Linda, interview)

Calesia felt that giving the feedback directly on the students' printed paper was better than using MS Word. She detailed her thoughts in the interview.

When giving feedback on my students' work, I still preferred giving notes on the paper to provide specific feedback and write various symbols, such as an underline to indicate a fragment and a wavy line to show an unnatural sentence. I could also circle some sentences and provide comments. When I did these in MS Word, I felt that my comments were not clear, specifically when there were many problems in one sentence related to fragments and choice of words. My students usually asked me to explain my comments further. (Calesia, interview)

Meanwhile, Sandra asked her students to submit their first draft in a Google Drive that she prepared. Later, she opened the draft on Google Docs and gave the feedback online with the assumption that all of her students were familiar with the use of Google Drive and Google Docs. However, she revealed some problems with these practices in the interview.

There were some problems. First, not all students were familiar with Google Drive. Second, some students did not have a laptop. Actually, by working in pairs, one laptop could be used for two students. However, the laptop was still not accessible for some pairs. Third, the Internet connection in the classroom 
was not stable. I had sent my feedback, but some of my students said they could not open my feedback. They needed time to open it in the classroom. Some pairs were confused about dropping the file to Google Drive, so they told me that they preferred to send their work to WhatsApp. (Sandra, interview)

\section{Theme 6: Plagiarism from the Internet was a concern}

A plagiarism case was reported in Linda's class. She explained that some students seemed to copy and paste a sentence from the Internet.

On some occasions, I allowed my students to use their mobile phones in the classroom to access online sources. However, some students misused it. They just copied and pasted ideas from the Internet. One day, I read one particular sentence that was too sophisticated and used uncommon vocabulary. When I asked my students to explain the sentence, they could not do it. (Linda, interview)

\section{Theme 7: Google Translate negatively affected sentences}

Google Translate application was also used to translate an Indonesian word to English without knowing the specific word's context. It was also used to write sentences, reported by Calesia in the interview.

In the second essay, the students wrote a favorite food recipe of their family, and one group wrote a recipe about tahu rambutan [a kind of tofu]. One of the instructions they wrote was "damage the tofu until it is fully destroyed." I asked the group how they could write the sentence, and they said that they used Google Translate to find the vocabulary. Then, I told them that they wanted to make tofu, but it felt like they wanted war. (Calesia, interview)

Responding to the issue, Calesia suggested her students use a more reliable online dictionary, such as Cambridge (https://dictionary. cambridge.org/us/) or Merriam Webster (https://www.merriamwebster.com/), which would show the context of the word so that they could select an English word more appropriately. We concur with the view that these kinds of dictionaries "provide students with corpus to help find natural and typical examples about how words and phrases are used" (Dudeney \& Hockly, 2012, p. 535).

\section{Discussion}

This research explored how technology was used to support the students' writing process and how the technology integration in the classroom hinders or facilitates the students to complete their EFL writing 
tasks. While the findings resulted in seven different themes, we would like to discuss some commonalities. In the planning stage, the data showed that all lecturers had similar practices in asking their students to create a flowchart clarifying ideas in their essay, put it in a PowerPoint slide, and present it to the class. These practices were considered beneficial because the students could talk about their essays and gain constructive input from their classmates and lecturer. Although "using the PowerPoint presentation is no longer special as teachers use it for daily teaching and learning activities" (Cahyani \& Cahyono, 2012, p. 135), our study found that the use of PowerPoint (e.g., coupled with the flowchart) was still fruitful to help students gather and organize ideas. This finding continues the practices in the previous studies (e.g., Mohammed, 2015; Park \& Son, 2009; Ruggiero \& Mong, 2015) when teachers still used PowerPoint as a teaching tool in their classrooms.

Another activity in the planning stage was doing the online search by allowing the students to visit any online websites that provide ideas for their outline. This practice is similar to what some teachers did in the past. For instance, they used websites "to search and find the material for the assignment" (Cahyani \& Cahyono, 2012, p. 136). The websites could also provide "numerous authentic resources and samples to help students review and compose their writing" (Park \& Son, 2009, p. 91). However, we were concerned that our respondents did not instruct their students about carefully selecting websites that might provide trustworthy and credible information. We had a similar assumption that students might evaluate a site mainly based on its appearance; "if it looks good, appears to be professional, and has a lot of detail on it, many of the students will accept it as a good website for information" (Walraven, et al., 2009, p. 245).

As students gradually rely more on web-based resources to look for information (Hammett, 1999), some studies suggest some criteria to evaluate learning websites, particularly those used in English language classrooms. For example, a reliable site usually has up-to-date information, has no grammatical errors (Walraven et al., 2009), is easy to navigate, and has a user-friendly interface (Chiou et al., 2010). Moreover, the website "has a search function, is free of charge, and provides information on the sources and authors" (Liu et al., 2011, p. 73). Discussing evaluation criteria and practicing evaluating the online source in a class might need to be done because "the evaluation of information sources is critical to successful learning" (Wiley et al., 2009, p. 1060). We expected that the students could be navigated to use reliable information from trustworthy sources to develop their essay and not be "ill-informed" by any uncredible information 
(Domonoske, 2016, Nov. 23). For various classroom activities on evaluating online sources, see Coiro (2014), Hammett (1999), and Wiley et al. (2009).

The findings showed that two lecturers (Linda and Calesia) preferred to ask their students to write on paper and later gave feedback on the same paper. Those practices enabled them to provide more detailed feedback (e.g., underlining or circling words or sentences) than the same practices done electronically, such as through MS Word, email, or Google Docs. Although previous researchers (e.g., Cahyani \& Cahyono, 2012; Li \& Ni, 2011; Muslem et al., 2018) consistently found that teachers frequently used email and word processing in their teaching practices, we reinforced Egbert's (2017) argumentation that teachers do not always need to use technology if goals can be achieved and content can be better learned without technology. In a similar vein, Hutchison and Woodward (2013) mentioned that paper and pencil should be used if they could contribute to teaching instructions with fewer barriers than those of using technology. From the data, we could also see how Google Docs was used to submit and receive feedback. However, the practice was not smooth as most students were not familiar with the application, the Internet connection was not stable, and not all students had a laptop to open the file in the classroom. Therefore, teachers should always consider possible constraints when using technology so that "the constraints do not overpower their instructional goal" (Hutchison \& Woodward, 2013, p. 8).

Further, the use of the online dictionary, as revealed in the data, was consistent with teachers' practices in various settings, such as in Turkey (Mohammed, 2015), Vietnam (Tri \& Nguyen, 2014), and Indonesia (Muslem et al., 2018). This finding might indicate that the use of the dictionary is still with us today. The finding might also mean that lecturers do not always need to use the newest and most sophisticated technology to facilitate their students' EFL writing process.

In the editing and revising stage, one lecturer (Calesia) used YouTube videos to provide supplementary explanations to respond to the students' common grammatical problems (e.g., run-on sentences and fragments). The current study detailed teaching-related decisions that encouraged Calesia to use the video (e.g., attracting her students' attention and making them listen to authentic explanations in English) and activities that followed (e.g., taking notes, discussing questions, and revising the problems in the essay). Calesia's teaching decisions were in line with teachers' beliefs that "using technology can make the teaching and learning process more interesting; the students will have more attention to the subject" (Cahyani \& Cahyono, 2012, p. 138). In a large-scale study involving 1653 students in two universities in 
Australia, Henderson et al. (2017) found that watching videos from sources outside universities (11.7\%) were cited among the most useful digital technology practices for university students, allowing them to view content dynamically. While Calesia referenced the Smart English YouTube channel, we believe that other related sources need to be explored. For example, "the how-to paragraph or essay is a genre that lends itself well to the use of YouTube" (Watkins \& Wilkins, 2011, p. 117). As a supplement to YouTube videos, EFL lecturers might consider using some online grammar checkers. Although they could not detect all grammatical problems in students' writing, some researchers (e.g., see Park, 2019; Yang, 2018) reported that the grammar checkers could check errors related to verb-tense, verb form, prepositions, and subject-verb agreement.

Unfortunately, the plagiarism case from the Internet emerged in the data. The finding confirms that plagiarism has happened with the emergence of the Internet, which provides easy access for students to plagiarize (see Ali et al., 2012; Eret \& Ok, 2014). Explaining clearly about citing online sources and academic honesty in the course syllabi might be a good start. It should be followed by regular classroom discussions about cutting and pasting from online sources (see Scanlon, 2003). The discussion could also cover the use of Google Translate in the students' writing, which, as evident in the research data, failed to provide sentence-level translations with proper contexts and grammatical aspects. In line with this finding, previous researchers (Chandra \& Yuyun, 2018; Vidhayasai et al., 2015) found out that Google Translate might work with a single-word translation, although it still needs sensible judgments from its users. Last, the seven themes in the findings that detailed what the research participants did with the technology show that this study has gone beyond exploring types of technology for educational purposes or teachers' attitudes on technology as what has been done by previous researchers (e.g., Aydin, 2013; Cahyani \& Cahyono, 2012; Celik, 2013; Cummings, 2008; Mohammed, 2015; Muslem et al., 2018; Park \& Son, 2009; Ruggiero \& Mong, 2015).

\section{CONCLUSIONS}

The study came up with the following conclusions. First, the participants used various technology applications (see Table 3 ) in the writing processes except in the submitting stage. Second, PowerPoint supported with the (online) flowcharts successfully facilitated the students' writing process in the planning stage. Third, the technology applications in the drafting, editing, and revising stages were mostly used to submit work and provide 
feedback. However, two lecturers preferred giving the feedback directly on their students' printed paper after considering some issues that happened when using technology in those stages. Fourth, plagiarism and the use of Google Translate were issues of concern during the EFL writing process. Fifth, lecturers do not always need to find the newest and most sophisticated technology to facilitate their students' writing process. As evidence in the data, "simple" technology, such as PowerPoint and online dictionaries, still can support the students' writing activities. Last, technology applications should not always be used in each writing stage (during the planning, drafting, editing, revising, and submitting stages), mainly when the applications cause some (technical) barriers for students in completing their EFL writing tasks.

In closing, we propose some directions for future research. The participants of the present study are all female. When this study was conducted, two of them were in their forties, and one of them was in her late thirties. We do not know if male and/or younger participants will have similar technological practices in the writing class. Moreover, the current research was conducted in an EFL writing class in an undergraduate setting in Indonesia before the COVID-19 pandemic. Future research might follow up on the study by exploring the use of technology in a similar setting, particularly in the master's or doctoral levels, during the pandemic situation either in Indonesia or overseas countries where students write a longer text or more formal writing (e.g., a scholarly text or dissertation). It will also be interesting to conduct similar explorations in a writing class with better technology equipment and Internet connection. Further, the reflective checklist and interview questions used in this study should be replicated by future researchers to explore similar issues involving more participants and students' voices on how their lecturers use technology in the five stages of the writing process. Future researchers can also complement our study's findings by looking at teaching and learning activities with technology more closely; they should video-record class activities or use other classroom observation techniques (e.g., field notes) in their exploration. Our study appears to have provided avenues for increasing the effectiveness of individual EFL teachers' instructions with the best and wisest use of technology to respond to the global, national, and local policies in higher education contexts. 


\section{REFERENCES}

Agada, J. (1998). Multicultural education and the emerging paradigm: An essay in cultural epistemology. The Urban Review, 30(1), 77-95. https://doi.org/10.1023/A:1023289429871

Ali, W. Z. W., Ismail, H., \& Cheat, T. T. (2012). Plagiarism: To what extent it is understood? Procedia Social and Behavioral Sciences, 59, 604611. https://doi.org/10.1016/j.sbspro.2012.09.320

Al-Kathiri, F. (2015). Beyond the classroom walls: Edmodo in Saudi Secondary School EFL instruction, attitudes, and challenges. English Language Teaching, 8(1), 189-204. https://doi.org/10.5539/elt.v8n1p189

Almas, A. G., \& Krumsvik, R. (2008). Teaching in technology-rich classrooms: Is there a gap between teachers' intentions and ICT practices? Research in Comparative and International Education, 3(2), 103-121. https://doi.org/10.2304/rcie.2008.3.2.103

Ary, D., Jacobs, L. C., Irvine, C. K. S., \& Walker, D. A. (2019). Introduction to research in education $\left(10^{\text {th }} \mathrm{ed}\right.$.). Cengage.

Aydin, S. (2013). Teachers' perceptions about the use of computers in EFL teaching and learning: The case of Turkey. Computer Assisted Language Learning, 26(3), 214-233. https://doi.org/10.1080/09588221.2012.654495

Aydin, Z., \& Yildiz, S. (2014). Using wikis to promote collaborative EFL writing. Language Learning and Technology, 18(1), 160-180. http://dx.doi.org/10125/44359

Cahyani, H., \& Cahyono, B.Y. (2012). Teachers' attitudes and technology use in Indonesian EFL classrooms. TEFLIN Journal, 23(2), 130-148. $\mathrm{http} / / / \mathrm{dx}$. doi.org/10.15639/teflinjournal.v23i2/130-148

Celik, S. (2013). Internet-assisted technologies for English language teaching in Turkish universities. Computer Assisted Language Learning, 26(5), 468-483. https://doi.org/10.1080/09588221.2012.692385

Chandra, S. O., \& Yuyun, I. (2018). The use of Google Translate in EFL essay writing. LLT Journal: A Journal on Language and Language Teaching, 21(2), 228-238. https://doi.org/10.24071/llt.2018.210212

Chang, W. Y. (2020). Exploring solutions to decrease Taiwanese university lower achievers' English writing difficulties via blogging. CALL-EJ, 21(2), 114-131. http://callej.org/journal/21-2/Chang2020.pdf

Chiou, W., Lin, C., \& Perng, C. (2010). A strategic framework for website evaluation based on a review of the literature from $1995-2006$. 
Mali \& Salsbury, Technology Integration in EFL Writing Classroom 261

Information \& Management, 47(5-6), 282-290. https://doi.org/10.1016/j.im.2010.06.002

Clandinin, D. J. (2006). Narrative inquiry: A methodology for studying lived experience. Research Studies in Music Education, 27(1), 44-54. https://doi.org/10.1177/1321103X060270010301

Coiro, J. (2014). Teaching adolescents how to evaluate the quality of online information. Edutopia. https://www.edutopia.org/blog/evaluatingquality-of-online-info-julie-coiro

Creswell, J. W. (2014). Research design: Qualitative, quantitative, and mixed method approaches. SAGE Publications Ltd.

Cummings, A. (2008). Spanish teachers' beliefs and practices on computers in the classroom. Hispania, 91(1), 73-92. https://doi.org/10.2307/20063625

Dewey, J. (1933). How we think: A restatement of the relation of reflective thinking to the educative process. Henry Regnery.

Directorate General of Higher Education Ministry of Education and Culture Republic of Indonesia. (2015). Indonesian Qualification Framework: Implication and implementation strategies. http://kkni.kemdikbud.go.id/asset/pdf/iqf_booklet_(english).pdf

Domonoske, C. (2016, November 23). Students have 'dismaying' inability to tell fake news from real, study finds. The Two-Way, National Public Radio (NPR), USA. https://www.npr.org/sections/thetwoway/2016/11/23/503129818/study-finds-students-have-dismayinginability-to-tell-fake-news-from-real

Dudeney, G., \& Hockly, N. (2012). ICT in ELT: How did we get here and where are we going? ELT Journal, 66(4), 533-542. https://doi.orgwal/10.1093/elt/ccs050

Egbert, J. (2017). Methods of education technology: Principles, practice, and tools. Open Educational Resources (OER). https://opentext.wsu.edu/tchlrn445

Eret, E., \& Ok, A. (2014). Internet plagiarism in higher education: Tendencies, triggering factors and reasons among teacher candidates. Assessment \& Evaluation in Higher Education, 39(8), 1002-1016. https://doi.org/10.1080/02602938.2014.880776

Farrell, T. S. C. (2015a). Promoting teacher reflection in second language education: A framework for TESOL professionals. Routledge. https://doi.org/10.4324/9781315775401

Farrell, T. S. C. (2015b). Reflecting on teacher-student relations in TESOL. ELT Journal, 69(1), 26-34. https://doi.org/10.1093/elt/ccu033 
Ferris, D. R., \& Hedgcock, J. S. (2014). Teaching L2 composition: Purpose, process, and practice (3rd ed.). Routledge. https://doi.org/10.4324/9780203813003

Fraenkel, J. R., \& Wallen, N. E. (2009). How to design and evaluate research in education (7th ed.). The McGraw-Hill Companies, Inc.

Gage, N. L. (1989) The paradigm wars and their aftermath: A "historical" sketch of research on teaching since 1989. Educational Researcher, 18(7), 4-10. https://doi.org/10.3102/0013189X018007004

Gun, B. (2011). Quality self-reflection through reflection training. ELT Journal, 65(2), 126-135. https://doi.org/10.1093/elt/ccq040

Hammett, P. (1999). Teaching tools for evaluating world wide web resources. Teaching Sociology, 27(1), 31-37. https://doi.org/10.2307/1319243

Harmer, J. (2007). The practice of English language teaching ( ${ }^{\text {th }}$ ed.). Pearson Education Limited.

Henderson, M., Selwyn, N., \& Aston, R. (2017). What works and why? Student perceptions of 'useful' digital technology in university teaching and learning. Studies in Higher Education, 42(8), 1567-1579. https://doi.org/10.1080/03075079.2015.1007946

Hutchison, A., \& Woodward, L. (2013). A planning cycle for integrating digital technology into literacy instruction. The Reading Teacher, 67(6), 455-464. https://doi.org/10.1002/TRTR.1225

Jiang, H. (2015). A Chinese learner and her self-regulated learning: An autoethnography. Frontier of Education in China, 10(1). 132-152.

Laksmi, E. D. (2006). "Scaffolding" students' writing in EFL Class: Implementing process approach. TEFLIN Journal, 17(2), 144-156. https://doi.org/10.15639/teflinjournal.v17i2/152-165

Lewis, K. A. (2018). A digital immigrant venture into teaching online: An autoethnographic account of a classroom teacher transformed. The Qualitative Report, 23(7), 1752-1772. https://doi.org/10.46743/2160$3715 / 2018.3036$

Li, G., \& Ni, X. (2011). Primary EFL teachers' technology use in China: Patterns and perceptions. RELC Journal, 42(1), 69-85. https://doi.org/10.1177/0033688210390783

Liu, G., Liu, Z., \& Hwang, G. (2011). Developing multi-dimensional evaluation criteria for English learning websites with university students and professors. Computers \& Education, 56(1), 65-79. https://doi.org/10.1016/j.compedu.2010.08.019

Mali, Y. C. G. (2015). Blog as a pedagogical application in learning creative writing. Widya Dharma, 28(1), 48-67. 
Mali, Y. C. G., \& Timotius, A. I. (2018). Project based activities in a call classroom: EFL students' experiences. International Journal of Education, 11(1), 6-17. https://doi.org/10.17509/ije.v11i1.10177

Mindog, E. (2016). Apps and EFL: A case study on the use of smartphone apps to learn English by four Japanese university students. JALTCALL Journal, 12(1), 3-22. https://eric.ed.gov/?id=EJ1107946

Mohammed, M. I. (2015). The perception of students and teachers about the benefits of and barriers to technology aided EFL. Journal of Literature, Languages and Linguistics, 13(2010), 85-100. https://doi.org/10.1177/2158244012440813

Muñoz, A., \& Ramirez, M. (2015). Teachers' conceptions of motivation and motivating practices in second-language learning: A self-determination theory perspective. Theory and Research in Education, 13(2), 198-220. https://doi.org/10.1177/1477878515593885

Muslem, A., Yusuf, Y. Q., \& Juliana, R. (2018). Perceptions and barriers to ICT use among English teachers in Indonesia. Teaching English with Technology, 18(1), 3-23. https://eric.ed.gov/?id=EJ1170638

Nation, I. S. P. (2009). Teaching ESL/EFL reading and writing. Routledge.

Pang, A. (2017). Reflective teaching and practice: Interview with Thomas Farrell. RELC Journal, 48(2), 174-179. https://doi.org/10.1177/0033688217707632

Pardo, A. N., \& Tellez, M. F. T. (2015). Reflection on teachers' personal and professional growth through a materials development seminar. $\mathrm{HOW}$, 22(2), 54-74. https://doi.org/10.19183/how.22.2.151

Park, C. N., \& Son, J. B. (2009). Implementing computer-assisted language learning in the EFL classroom: Teachers' perceptions and perspectives. International Journal of Pedagogies and Learning, 5(2), 80-101. https://doi.org/10.5172/ijpl.5.2.80

Park, J. (2019). An AI-based English grammar checker vs. human raters in evaluating EFL learners' writing. Multimedia-Assisted Language Learning, 22(1), 112-131. https://www.kci.go.kr/kciportal/ci/sereArticleSearch/ciSereArtiView.k ci?sereArticleSearchBean. artiId=ART002449524

Parvin, R. H., \& Salam, S. F. (2015). The effectiveness of using technology in English language classrooms in government primary schools in Bangladesh. Forum for International Research in Education, 2(1), 4759. https://doi.org/10.18275/fire201502011049

Pearcy, M. (2014). Student, teacher, professor: Three perspectives on online education. The History Teacher, 47(2), 169-185. https://www.jstor.org/stable/43264218 
Ruggiero, D., \& Mong, C. J. (2015). The teacher technology integration experience: Practice and reflection in the classroom. Journal of Information Technology Education: Research, 14, 161-178. https://eric.ed.gov/?id=EJ1084455

Safdari, M. (2021). Contributions of Edmodo social learning network to Iranian EFL learners' writing accuracy. CALL-EJ, 22(1), 343-361. $\mathrm{http} / /$ callej.org/journal/22-1/Safdari2021.pdf

Sanchez, J., Salinas, A., \& Harris, J. (2011). Education with ICT in South Korea and Chile. International Journal of Educational Development, 31(2), 126-148. https://doi.org/10.1016/j.ijedudev.2010.03.003

Scanlon, P. M. (2003). Student online plagiarism: How do we respond? College Teaching, 51(4), 161-165. https://doi.org/10.1080/87567550309596432

Singh, T K. R., \& Chan, S. (2014). Teacher readiness on ICT integration in teaching-learning: A Malaysian case study. International Journal of Asian Social Science, 4(7), 874-885. http://www.aessweb.com/pdffiles/ijass-2014-4(7)-874-885.pdf

Son, J.-B., Robb, T., \& Charismiadji, I. (2011). Computer literacy and competency: A survey of Indonesian teachers of English as a foreign language. Computer-Assisted Language Learning Electronic Journal (CALL-EJ), 12(1), 26-42. http://callej.org/journal/12-1/Son_2011.pdf

Sylvestre, M., Haiyan, H., \& Yiyi, Z. (2018). Information communication technology policy and public primary schools' efficiency in Rwanda. South African Journal of Education, 38(1), 1-10. http://dx.doi.org/10.15700/saje.v38n1a1445

Tompkins, G. E. (1994). Teaching writing: Balancing process and product $\left(2^{\text {nd }}\right.$ ed.). Macmillan.

Torabi, S. (2021). Blended learning (B-learning) via Google Classroom (GC) and Iranian EFL learners' writing accuracy: Effects and percepts. CALLEJ, 22(3), 183-199. http://callej.org/journal/22-3/Torabi2021.pdf

Tri, D. H., \& Nguyen, N. H. T. (2014). An exploratory study of ICT use in English language learning among EFL university students. Teaching English with Technology, 14(4), 32-46. https://eric.ed.gov/?id=EJ1143398

Trinder, R. (2017). Informal and deliberate learning with new technologies. ELT Journal, 71(4), 401-412. https://doi.org/10.1093/elt/ccw117

Umar, I. N., \& Yusoff, M. T. M. (2014). A study on Malaysian teachers' level of ICT skills and practices, and its impact on teaching and learning. Procedia - Social and Behavioral Sciences, 116, 979-984. https://doi.org/10.1016/j.sbspro.2014.01.331 
UNESCO Asia Pacific Regional Bureau for Education. (2013). ICT in education: Policy, infrastructure and ODA status in selected ASEAN countries. UNESCO Bangkok.

Vidhayasai, T., Keyuravong, S., \& Bunsom, T. (2015). Investigating the use of google translate in "terms and conditions" in an airline's official website: Errors and implications. PASAA, 49, 137-169. https://eric.ed.gov/?id=EJ1077919

Walraven, A., Gruwl, S. B., \& Boshuizen, H. P. A. (2009). How students evaluate information and sources when searching the World Wide Web for information. Computers \& Education, 52(1), 234-246. https://doi.org/10.1016/j.compedu.2008.08.003

Watkins, J., \& Wilkins, M. (2011). Using YouTube in the EFL classroom. Language Education in Asia, 2(1), 113-119. https://doi.org/10.5746/leia/11/v2/i1/a09/watkins_wilkins

Wiley, J., Goldman, S. R., Graesser, A. C., Sanchez, C. A., Ash, I. K., \& Hemmerich, J. A. (2009). Source evaluation, comprehension, and learning in internet science inquiry tasks. American Educational Research Journal, 46(4), 1060-1106. https://doi.org/10.3102/0002831209333183

Yang, H. (2018). Efficiency of online grammar checker in English writing performance and students' perceptions. Korean Journal of English Language and Linguistics, 18(3), 328-348. http://dx.doi.org/10.15738/kjell.18.3.201809.328

Yu, L. T. (2018). Incorporating Facebook into an EFL writing course: Student perception and participation in online discussion. CALL-EJ, 19(1), 122. http://callej.org/journal/19-1/Yu2018.pdf 


\section{Appendix}

\section{The Interview Questions}

\section{Demographic Information}

1. What is your gender identity?

2. How old are you?

3. What is your highest education degree?

4. How long have you been teaching at the university?

5. Where are you from (nationality)?

\section{Technological Experiences}

6. How is the technology used during the lesson (e.g., in the students' writing process)?

Can you give an example?

7. How do you provide instructions for your students to use the technology to support their writing process? Can you give an example?

8. What does technology do well to support the writing process? Can you give an example?

9. What do you learn from these successful experiences? Can you give an example?

10. What doesn't technology do well to support the writing process? Can you give an example?

11. What do you learn from these unsuccessful experiences? Can you give an example?

12. Do you believe that the use of technology facilitates the students to complete their writing tasks? Why? 